\title{
Presbyterian Indians in South Africa
}

\begin{tabular}{|c|c|}
\hline $\begin{array}{l}\text { Author: } \\
\text { Jerry Pillay }\end{array}$ & \\
\hline $\begin{array}{l}\text { Affiliation: } \\
{ }^{1} \text { Department } \\
\text { History and } \mathrm{Cl} \\
\text { Faculty of The } \\
\text { University of } \\
\text { South Africa }\end{array}$ & $\begin{array}{l}\text { f Church } \\
\text { urch Polity, } \\
\text { ology, } \\
\text { retoria, }\end{array}$ \\
\hline $\begin{array}{l}\text { Project leade } \\
\text { Project numb }\end{array}$ & $\begin{array}{l}\text { : J. Pillay } \\
\text { er: } 04653484\end{array}$ \\
\hline $\begin{array}{l}\text { Description: } \\
\text { This research } \\
\text { project, 'Africa } \\
\text { and Developm } \\
\text { by Prof. Dr Jer } \\
\text { Department o } \\
\text { History and Cl } \\
\text { Faculty of The } \\
\text { University of } \\
\text { South Africa }\end{array}$ & $\begin{array}{l}\text { s part of the } \\
\text { in Christianity } \\
\text { ent', directed } \\
\text { ry Pillay, } \\
\text { f Church } \\
\text { uurch Polity, } \\
\text { ology, } \\
\text { retoria, }\end{array}$ \\
\hline $\begin{array}{l}\text { Correspondin } \\
\text { Jerry Pillay, } \\
\text { jerry.pillay@u }\end{array}$ & $\begin{array}{l}\text { g author: } \\
\text { p.ac.za }\end{array}$ \\
\hline $\begin{array}{l}\text { Dates: } \\
\text { Received: } 071 \text { I } \\
\text { Accepted: } 27 \\
\text { Published: } 31\end{array}$ & $\begin{array}{l}\text { Mar. } 2016 \\
\text { May } 2016 \\
\text { Aug. } 2016\end{array}$ \\
\hline $\begin{array}{l}\text { How to cite th } \\
\text { Pillay, J., } 2016 \\
\text { Indians in Sou } \\
\text { Teologiese Stu } \\
\text { Theological St } \\
\text { a3402. http:// } \\
\text { org/10.4102// }\end{array}$ & $\begin{array}{l}\text { is article: } \\
\text { 'Presbyterian } \\
\text { th Africa', HTS } \\
\text { dies/ } \\
\text { udies 72(1), } \\
\text { dx.doi. } \\
\text { its.v72i1.3402 }\end{array}$ \\
\hline $\begin{array}{l}\text { Copyright: } \\
\text { (c) 2016. The } \\
\text { Licensee: AOS } \\
\text { is licensed un } \\
\text { Creative Comr } \\
\text { Attribution Lic }\end{array}$ & $\begin{array}{l}\text { ISthors. } \\
\text { IS. This work } \\
\text { der the } \\
\text { nons } \\
\text { ense. }\end{array}$ \\
\hline Read online: & \\
\hline 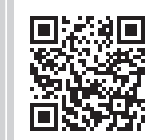 & $\begin{array}{l}\text { Scan this QR } \\
\text { code with your } \\
\text { smart phone or } \\
\text { mobile device } \\
\text { to read online. }\end{array}$ \\
\hline
\end{tabular}

In this article the author traces the origins and development of Indians in the Uniting Presbyterian Church in Southern Africa. He acknowledges the work of the founder of the Indian Presbyterian work, the Rev. Joseph Prakasim, looks at the expansion of Presbyterianism among the Indian population in South Africa and shows how through various ministries these congregations contributed to the development of the Indian communities in South Africa, impacting on the country as a whole.

\section{Introduction}

Nothing has really been written about Presbyterian Indians in South Africa. This research attempts to briefly trace the work of Indians within the Uniting Presbyterian Church in Southern Africa (UPCSA), making reference to its early pioneers, offering information on the development and expansion of churches in Indian communities and giving a brief description of their ministries and current situation. However, before we attempt this exercise we shall first provide some information about Presbyterianism in general and then briefly trace Presbyterianism in Southern Africa.

The Presbyterian family of churches, like all Christian churches, traces its roots back to the early church in Jerusalem, to Paul and the church fathers like Augustine (Dalziel 1982) In 1517 Martin Luther nailed his 95 Theses to a church door in Wittenberg, Germany. This public challenge to the practices of the church of his time led to the formation of a new family of churches known as the Protestant churches. The two main branches of Protestant churches are the Reformed churches and the Lutheran churches. The Presbyterian Church belongs to the Reformed family.

John Calvin, born in France in 1509, has been called the 'Father of Presbyterianism'. Calvin's legacy to us is found in his teaching on the sovereignty of God, the priesthood of all believers and the Presbyterian Church structure. His ideals of morality, ethics and democracy helped shaped Western thought. From Geneva Presbyterians spread to Scotland and Ireland mainly through John Knox, who studied under John Calvin, and to England, the Netherlands and America. Throughout the world today there are some 80 million men, women and children who belong to the Christian family that goes by the name of 'Reformed and Presbyterian'. Included in this family is the UPCSA.

\section{Presbyterianism in Southern Africa}

In 1806 Britain sent the Argyle and Sutherland Highlanders Regiment to the Cape as an occupying force. These Scottish soldiers were an unusually devout group of Presbyterians who met every week for prayer, Bible study and public worship. In 1812 a Presbyterian minister, the Rev. George Thorn, on his way to India as a missionary with the London Missionary Society arrived in the Cape and decided to stay with the regiment. He then established the first Presbyterian congregation, which suffered a setback when he resigned in 1818 . However, this setback was only temporary: in 1824 the congregation was re-established, and the building was completed in 1827 and it stands to this day in Cape Town, where it is known as the 'Mother Church'.

In 1821 the Glasgow Missionary Society sent its first missionaries to work in the Eastern Cape. In 1824 they established the Lovedale mission, which became famous under the leadership of the Rev. Dr. James Steward. According to Graham Duncan, Dr. Steward 'was destined to become a missionary giant of his time' (Duncan 2003:146). As early as 1823 a presbytery was formed and the churches spread rapidly throughout the whole Eastern Frontier. In due course the work was divided into three presbyteries: Kaffraria, Mankazana and Transkei. The first church was built at Glen Lynden in 1828.

Organised Presbyterianism began in Natal on the evening of 28 October 1850 when a gathering of Presbyterians resolved to form themselves into a congregation with the name the Presbyterian 
Church of Natal. The Rev. William Campbell, from Scotland, accepted a call to the young congregation on 16 March 1851. The growth of the Presbyterian Church in other parts of South Africa followed in the wake of the Great Trek beginning in 1830, the discovery of diamonds in the Northern Cape in 1870 and gold on the Witwatersrand in 1886. In 1896 the first Presbyterian congregation in Zimbabwe was formed in Bulawayo and in 1903 another at Harare, with others soon following. The first Presbyterian congregation in Zambia was established in 1926 at Livingstone and many more were formed thereafter throughout Zambia (Adamson 2003).

Largely through the initiative of the Rev. John Smith of Pietermaritzburg, the first General Assembly of the Presbyterian Church met in Durban in 1897 with him as its moderator. This General Assembly brought together the presbyteries of Cape Town, Natal and the Transvaal; the white congregations of the Synod of Kaffraria (Free Church of Scotland) and the presbytery of Adelaide (United Presbyterian Church of Scotland); and the two independent congregations at Port Elizabeth and Kimberley. As this church expanded and included work in the countries north of South Africa, its name was also expanded to the Presbyterian Church of Southern Africa (PCSA) (Rodger 1998).

Parallel to this, the majority of Free Church of Scotland mission congregations did not join the PCSA, in particular those of the Eastern Cape and other rural areas. The Scottish missionaries of the Free Church had concluded that joining would not be in the interest of the African Missions. These then formed into the Bantu Presbyterian Church in 1923, which then became known as the 'Reformed Presbyterian Church of South Africa' (RPCSA). Duncan points out that two other Presbyterian churches were operating in South Africa at the time: the Presbyterian Church of Africa, a church born from Pambani Mzimba's secession from the Scottish Mission in 1898, and the Swiss Mission in Africa, a church present in the Northern Transvaal and in Mozambique (Duncan \& Denis 2011:15).

After the inauguration of a democratically elected government in 1994, discussions between the RPCSA and PCSA were re-opened at the initiative of the RPCSA. In 1997 both assemblies referred a draft Basis of Union to their presbyteries with a view that a new united church could be established (General Assembly Papers 1996). Consequently, on 26 September 1999 the UPCSA was established to fully express God's unity in the new South Africa, and the name 'Uniting' was retained as an open door to the possibility of union with other Presbyterian or Reformed churches.

\section{Presbyterianism among South African Indians}

Embedded particularly in the history of the PCSA and now in the UPCSA is the story of the first Indian Presbyterians in South Africa (for more history see Calpin 1949). Although Indians first officially arrived in South Africa as indentured labourers in 1860 (Muller 1984:220), there was no real work among them by the Presbyterian Church. Brain points out that, in fact, the Presbyterians, like the Dutch Reformed Church, had white parishes only (Brain 1983:194). However, the Presbyterian work among Indians in South Africa all began with the development of a unique friendship and partnership between a university lecturer and an Indian library assistant. This relationship led to the formation of an Indian Presbyterian congregation and the dedication of the first Indian Presbyterian Church in Merebank (for details on other churches see De Gruchy 2004 and Hofmeyer \& Oosthuizen 1981). Dr. E.P. Reim, a senior lecturer in Mechanical Engineering at the University of Natal in Durban, felt the call to start Christian work among the Indian community in Durban. He was set apart as the first Presbyterian Missionary to Indian people in 1953 and within a few years he started many wayside Sunday schools, with over a thousand children mainly from Hindu backgrounds, spread all over Durban, assisted by many university students and professional men and women. He was no stranger to the Indian community, serving as the Joint Secretary of the IndoEuropean Council, which was set afoot by the then-Agent General of India, the Hon. Shrinivasa Sastri (The Presbyterian Leadership 1975). He presented a paper on Franchise for Indians to the South African Society for the Advancement of Science as well as a memorandum to a provincial commission related to Indians. Indeed, he was a bridge for race relations in his highly esteemed person and opened the door for this within the PCSA.

At the university, Dr Reim encountered Mr Joseph Prakasim, who worked in the library for several years. Joe, as he was lovingly known by many people, was no stranger to the Christian faith. His father and grandfather were among the thousands who came from India as labourers and helped to develop the sugar industry. They were Hindus, but Joe's father became a Baptist Christian convert and then a member of the Full Gospel Church under Pastor J.F. Rowlands, to which his mother already belonged. Joseph had only 7 years of formal schooling, but he enjoyed reading, learning and engaging in theological arguments. It is said that E.P. Reim would bring religious magazines for young Joe to look over, and in one of them he found an article setting forth a Presbyterian point of view that his Pentecostal upbringing could not accommodate. He consulted his mentor, Reim, on the propriety of writing to the author to dispute him. Reim pointed to the initials at the foot of the article: E.P.R. Joe's embarrassment was considerable, but from this episode came a lively friendship that resulted in Prakasim becoming a Presbyterian and an enthusiastic pioneer of the Indian work.

It is thus not surprising that in December 1958 he entered the Presbyterian Church as a missionary agent to embark upon a new mission work in the large Indian Group Area of Merebank, with further studies in the Presbyterian Laypreachers' Course. The first congregation worshipped in the garage of Mr and Mrs. E. G. Willie. Mr. Willie and Mrs. Grace Prakasim were the first members of the church and the 
Prakasim's eldest daughter, Desiree, was the first baby to be baptised. By December 1959, the first anniversary of the work at Merebank, the congregation had grown into a membership of 103 (55 members in full communion and 48 baptised children). This was a result of vigorous evangelism carried out to non-Christians, which took the form of personal visits to homes, distribution of tracts and gospel gramophone records in the vernacular, dialogue on Hinduism and Christianity, public screening of the Jesus film, pastoral care, etc. There were many who converted from Hinduism to Christianity with many incredible and powerful stories of how God worked in their lives bringing them to salvation and hope in Jesus Christ. Among those was Dr G.K. Nair, who was a leading figure in the Education Department for Indians. His daughter Charmaine Magdalene was baptised by Rev. Reim, and she later had the extraordinary opportunity to be blessed by Pope Paul VI on 17 December 1976.

With the increasing membership it was inevitable that Willie's garage would soon become too small for Sunday worship. Fortunately, the Durban Corporation made available a site for the church building, where the church is currently situated, and neighbouring Presbyterian congregations contributed financially to purchase the property and build on it. The congregation moved into the newly erected hall on 12 March 1961 and built the church, together with other facilities, in the years to follow. Some of the most historic moments within the life, work and witness of the Merebank church in those early years of Joseph Prakasim's time were as follows:

1. Vibrant evangelism continued to increase the membership of the church.

2. The ordination of the Rev. Joseph Prakasim on 29 November 1960 in the Frere Road Presbyterian Church by the moderator of the General Assembly, the Rev. R.B. Mitchell.

3. Rev. Joseph Prakasim conducted his first baptismal service at Merebank on 20 March 1960 and his first communion service on 27 March. The first adult to be baptised was Mr Victor Soobramoney Pillay, who later became a minister in the Presbyterian Church as well.

4. The completion of the church building, of which the foundation stone was laid on 2 August 1964 by the founder of the Indian Mission, Dr E.P. Reim. The church was later dedicated on 11 October 1964 by the Rev. A.R. De Villiers, the moderator of the Natal Presbytery, who was also the convener of the Indian Mission.

5. The joyous and reverent ordination of the Rev. Dr. Ernest Reim in Merebank Presbyterian Church. The service was conducted by the Rev. Cliff Huges and the ordination was performed by the moderator of the presbytery, the Rev. Patrick Montgomery, with the Rev. Andre de Villiers preaching the charge.

6. The ordination and induction of four new Indian elders: Messrs James Naidoo, George Soorie, A.M. Francis and Peter Govender. Later to be added were Messrs Chin Pillay and Joseph Pillay, with many more following in the years to come.
7. In 1967 Bishop Stephen Neill, who was connected with the World Council of Churches and at that time professor of Missions and Ecumenical Theology at Hamburg University, visited the Merebank church by arrangement of the Natal Christian Council. In the procession into the service were Revs. Goldie (Anglican), Alec Borain (Methodist) and John de Gruchy (Congregational). The bishop was welcomed and garlanded. He gave a short greeting in Tamil and preached a thought-provoking sermon titled 'Who is my neighbour?'

Many more special events and moments continued in the ministry of the Rev. Joseph Prakasim in the Merebank Presbyterian Church, spanning some 27 years in total before he left to take up a full-time position at Princeton in the USA. Perhaps most notable are the further increase in membership to over 350, the continued evangelism ministry and the start of a women's association under the leadership of Mrs Lilly Pillay. The women's ministry did much to empower and enable women, and they also embarked on ministry activities within the community. The empowerment of women was certainly a vital ministry within the community, given the 'cultural oppression' that women often faced. The church, in the midst of struggle and resistance, become a place of education and liberation for women. Although at first women were not part of the church session (council), it was only a matter of time until they were ordained as elders in the church.

The Merebank congregation had a vibrant youth ministry under the leadership of Errol Theophilus and later Jerry Pillay, both of whom eventually became ministers in the Presbyterian Church. The youth ministry drew together over a hundred young people under the leadership of Jerry Pillay in the late 1970s and early 1980s. The ministry amongst the youth did much to prevent young people from taking to the streets, getting drawn into drugs and alcohol abuse. It offered programmes in educational and vocational training and kept the youth busy in the week with soccer, netball and mission programmes within the community. This was a significant ministry that sustained a very positive impact on the youth in the community, given the adverse effects of apartheid and lack of opportunity for young people. Young people were encouraged to attend school and support was offered to students who needed help. The Indian community, refusing to submit to political pressure and the oppressive apartheid education system, took responsibility to educate its own and extended this in due course to other race groups in South Africa.

The congregation added young elders to the session, witnessed a blossoming Sunday School over the years and maintained faithful worship. It is thus not surprising that within a short space of time the congregation managed to attain the designation of a 'full status' congregation, meaning that they were now financially self-sufficient. The latter aspect was very important for Rev. Prakasim, who was by now the convener of the Indian Mission and believed that the Indian Mission should control its own money. He said: 
There is now more emphasis on fraternalism than on paternalism. Paternalism is the biggest weakness of the Christian missions in South Africa. Nonwhite churches are under the thumb of white churches and it is choking them. Some people criticize the independent churches in South Africa because their Christianity is mixed with some pagan practices. Some say they broke away because of the colour bar and so on, but underneath it all is the fact of being under the thumb of the missionaries. The missionaries suppressed the African expression of Christianity. In our Indian mission, we want to be free to grow. (The Presbyterian Leadership, March 1975)

Rev. Prakasim and the other Indian and black ministers in the PCSA at that time did much to challenge apartheid practices within the church. They insisted on fair treatment, just stipends and better working conditions. They recognised the plight and hardships of the communities they pastored and raised these issues in the presbytery meetings and General Assembly. John De Gruchy makes the point that the white Presbyterians gradually developed their own mission work and so became multiracial in principle, though seldom in practice, except in the higher courts of the church (De Gruchy 2004:16). However, the Presbytery Church Extension and Aid Committee became the place to vent their feelings and effect change and support for their struggling communities.

Apart from his pastoral care ability, which extended beyond his members to people of other faiths, his vision and leadership, his wide understanding of mission and his humility in service was his vision to help the poor and needy. Rev. Prakasim used his influence to arrange old-age pensions and disability grants for people in the community. He arranged for food hampers to be collected from neighbouring Presbyterian churches and distributed among the needy, both inside and outside of the congregation. He also organised bursaries from the wider Presbyterian Church for children who could not afford to attend school or university. The church played a pivotal role in educational development and in offering welfare services to the Merebank community. It was thus not surprising when Rev. Prakasim decided to enter politics and supported the Tricamerial System, a governance system that partially included Indian and coloured people but excluded the majority black population in South Africa. Prakasim's interest was to use this opportunity to work against racism but the Merebank community, which was politically very active and engaged, resisted any participation in such a political system of governance. Rev. Prakasim was ultimately forced to abandon this career when members of the community started to deface the church buildings.

Added to his ministry was his vision to plant new churches within the Indian communities and mentor students for the ministry. Through his work and service and that of Elders Chin Pillay, Joseph Pillay, George Soorie, Steven Pillay, Jayce Nulliah, Joel Reddy and Jimmy Ezekiel, preaching stations were started in Chatsworth, Phoenix, Verulam and Tongaat, with a further congregation under the latter in Umhlali. The Revs. James Naidoo, Victor Pillay and Tony Govender (all ordained together in 1974) were placed in Tongaat, Chatsworth and Verulam, respectively. Further Presbyterian ministers who came under Prakasim's supervision just before he left to take up a post in the Princeton Seminary were Errol Theophilus, Jonathan Chetty, Thomas Robert and Jerry Pillay. Rev. and Mrs Prakasim returned to South Africa upon their retirement from Princeton, where they left this world to enter into the eternal presence of Almighty God.

Rev. Prakasim was replaced by the Rev. Manuel Jacob, who faithfully served the Merebank church for almost 15 years. The Merebank church was then under the leadership of the Rev. Dan Budhram, who joined the congregation as its minister in 2008. Currently the Rev. Buhle Mpofu serves as its resident minister. We shall now offer some brief insight into the further development and expansion of the Indian Presbyterian churches.

\section{Expansion of Presbyterian Indian Churches}

\section{The Tongaat Congregations}

In 1961 Mr. James Naidoo joined the Merebank Presbyterian Church and in 1967 he was requested by the Revs. Frank Martek and Harold Munro to start a new work in an Indian community away from Durban. However, Naidoo only took up this challenge on 2 May 1971, when he started the new work in Tongaat. The first service took place in a council flat with just members of his family. But by God's grace within a period of 10 months 150 people were baptised, mainly converts from Hinduism. Rev. Naidoo's ministry seemed to be largely centred on healing of sicknesses and exorcism from demon possession. His ministry in these areas attracted a lot of people to the church, leading to rapid growth, and in 1973 a house, which was used as the manse and a place for worship, was purchased in Tongaat. It was at this house that the Rev. Harold Munro named the church the Shalom Presbyterian Church.

The congregation continued to grow quite rapidly and soon space became an issue, which then led to the renting of premises at a shopping centre in 1976. This, too, proved to be very small and in 1977 a hall was hired for Sunday services. The greatest joy arrived for Rev. Naidoo and his flock on 16 September 1979, when they were able to worship for the first time in their own church building erected with assistance from other Presbyterian churches. Since there were no other Indian Presbyterian churches within the radius of 100 kilometres north of Durban, Rev. Naidoo, together with his elders, established congregations in Verulam and Umhlali. At the time of his retirement in 1995, the Baptismal Register at Shalom confirms that there were over 800 people in membership, with a further 200 at Verulam and another 100 at Umhlali.

Rev. Naidoo, his wife Margaret and their children worked hard to build the church family. Margaret was instrumental in starting the women's association and choir, with the 
children assisting in worship. The emergent leadership took it even further with work in the community and the exercising of other ministries and projects. They too, like the Merebank church, had a huge impact on the community with their community-based programmes and projects, which varied from education to welfare and health ministries. Although the Rev. Naidoo left a very strong work in Tongaat and beyond at the time of his retirement, this has, unfortunately, fragmented over the last few years because of factions within the congregation. The Rev. Naidoo continued to serve in the Umhlali congregation until he was no longer physically able to; he passed away after a long illness on 12 July 2010. The work is still sustained by laypeople.

\section{The Northdale Presbyterian Church}

The Northdale Presbyterian Church started as part of a wayside Sunday school in 1961 at Lahore Road Grounds in Northdale by Mr Jock Mullen, Mr Pieter De Klerk and the late Miss Mona Gelling from the City Presbyterian Church. They were later joined by Mrs Doreen Mullan and Mr Rob Aurbuckle.

Services were held in the homes of the late Joshua and Ruth Prakasim and the late Rebecca Rajah. After a few months, premises were found at Mannie's Garage, in the old Greytown Road, where Sunday school and Sunday morning services were held. After a few years at Mannie's Garage, the congregation moved to the Northdale Civic Centre in 1974. The Sunday school grew to approximately 100 children and regular Sunday services were held for parents of these Sunday school children by Cecil Drennan, Mr Watson, Rev. Calvin Cook and Bob Samson. Notice was given for the Sunday school and the church to move out of the Civic Centre. This did not stop the work as it was held under trees for a few weeks.

On 6 October 1974, the use of the Seventh Day Adventist Church was used for services, which were conducted by the Rev. Manuel Jacob, who came from the Baptist church to assist and grow the Northdale Presbyterian Church. Land was then obtained at the corner of Badrudeen and Sharjah Roads, where the present church was built. The congregation grew under the ministry of Rev. M. Jacob and the new building was officially dedicated to the glory of God on 27 September 1980 by Mr. Jock Mullen. A grand service was held to celebrate this milestone in the work of the Presbyterian Church at Northdale. Rev. Manuel Jacob was then called to the Merebank Presbyterian Church in December 1985, where he eventually retired. He passed away in 2008. In December 1986, Rev. Jonathan Chetty was appointed minister. He resigned in January 1987 and moved to Johannesburg.

The Rev. Duncan Murray became overseer of Northdale with Elder Dickson Moodley conducting services from 1987 to 1992. The congregation declined in numbers as a result of having no minister. In 1992, Rev. Sipho Mthetwa assisted in the ministry but the church still faced many crises and trials. The presbytery wanted to close the doors at Northdale, as it was not financially viable for it to remain open. Through much fasting and prayer by a few faithful members, the church remained open.

In 1994, the Rev. Calvin Naidoo was minister until May 1995. In May 2005 Preggy Moodley was ordained as a lay preacher and placed in charge of the church by Rev. Calvin Naidoo, with Rev. Duncan as overseer and interim moderator. In 2006 the Rev. Duncan Murray found the church growing and running smoothly and applied for Preggy Moodley to be licensed to dispense the sacrament of baptism and communion and to conduct all services. The church is now active and ministries such as kids' club, Sunday school, youth club, men's fellowship, women's auxiliary and Sunday morning services are fully operational. Membership has now grown to 120 adults, 30 youth and 20 Sunday school children. Currently, it is a growing congregation continuing to make an impact on the community.

\section{The Chatsworth Congregation}

In 1970 the Merebank Presbyterian Church decided to direct its attention to starting a new church in Chatsworth, a large Indian community not too far away from Merebank. Rev. Prakasim and in particular Elders Chin Pillay and Joseph Pillay worked with the Rev. Victor Pillay in this community. They started by holding a wayside Sunday school, and they visited the parents of the children who attended, who were mostly not Christian. In 1971 a manse was secured and the Rev. Victor Pillay held services in his lounge, which soon extended into two rooms and then into an outside tent to accommodate the growing numbers. In 1975 the church hall was built with a generous gift of R35 000 from the Rev. Charles Gordon.

In November 1976 the foundation stone of the new Ernest Reim Memorial Presbyterian Church was laid by Mrs. Reim at a service conducted by the moderator of the Durban Presbytery, the Rev. Michael Wenning. In 1977, on the Sunday after the General Assembly, the congregation was blessed with a visit and sermon delivered by the newly inducted General Assembly moderator, the Rt Rev. H. Thomas.

The Rev. Victor Pillay, currently retired in Cape Town, enjoyed a very successful ministry in this congregation, seeing many converts from Hinduism joining the church. By the time he left in 1982 to take up a new charge in Cape Town, the congregation had a membership of over 200, maintained by six elders, and many vibrant ministries amongst the women, youth and children.

The Rev. Errol Theophilius later came to serve as minister for a few years before moving to another congregation in East London. During these years the church was very active within the community of Chatsworth. It housed a nongovernmental organisation known as Crisis Care, which led active campaigns against apartheid, validated the protest movement, used the church facilities to heighten the struggle for liberation and provided various types of practical care 
and support for the community. The church became a centre for political and economic freedom, of course, much to the dismay of the presbytery of Durban, which resisted politics in the church. Errol was followed by the Rev. Dan Francis, who ministered in this congregation for a further few years before taking a ministry charge in Port Elizabeth, then to Zambia, finally returning to South Africa, where he passed away a few years later. Currently, the congregation is led by the elders under an interim moderator.

\section{The Phoenix Congregation}

The Rev. Joseph Prakasim, together with some of the elders from the Merebank congregation, cast his eyes on the fastexpanding Indian community in Phoenix and felt a call to start a new work in this area, in 1976. They conducted openair services, visited people's homes and eventually held services on Sundays in a house availed to them in the Units 1-7 area. Rev. Prakasim met Jimmy Ezekiel, a student at the Durban Bible College for ministry in the Baptist Church at that time, and encouraged him to train for the Presbyterian ministry. Ezekiel joined the Merebank Presbyterian Church, was ordained as an elder and joined the pioneering work in Phoenix with his wife Priscilla, a devout Presbyterian he met at the Merebank church.

In 1980 Jimmy Ezekiel and his family were appointed to pioneer the work in the New Phoenix area from Units 7-24, known as the Gandhi Settlement in Unit 10, bordering on the Inanda informal settlement. Consequently, the Old Phoenix work was dissolved and the energy and effort was put into the work in the New Phoenix area. Ezekiel and his wife visited houses on foot and engaged in evangelistic activities in spite of the fact that he was in secular employment in Merebank. He started services in the home of his late mother in Unit 10 and, with the assistance of his brother, Nicodemus Ezekiel, formed a thriving Sunday school and maintained ministry during the week. When they ran out of space for their Sunday services, they moved to another house and then eventually to a large classroom in the Northmead Secondary School. A plot was procured in Unit 15 from the City Estates Department and was paid for in full by the Rev. Charles Gordon. Jimmy Ezekiel then resigned from his secular employment and went into full-time ministry and theological studies at Theological Education by Extension (TEEC) with financial assistance given by the Durban North Presbyterian Church. The elders assisted the development of the work into a preaching station, taking responsibility for the various ministries. Anthony Ganesan served as session clerk, Segren (a deacon) led the youth, Lenny Cooper led the cell meetings, Shireen and Cookie led the Sunday school ministry and Ronnie the Bible studies. During the latter period of 1982-1987, plans for a church building were produced and a church building was erected. It was used for services on Sunday, and throughout the week it was availed to community programmes and ministry, reaching very widely into the Phoenix community.
In 1987 Jimmy Ezekiel was ordained to the ministry of the Word and Sacrament and inducted as minister in a service held in the new church building, which was named Christ the Redeemer Presbyterian Church, situated in Unit 15, where it still stands. The congregation grew from 120 members to 150 and new elders were added to the session. Sadly, a dispute emerged amongst the elders, which led to a decline in the congregation. The appointment of new people and their contributions to the life and work of the church allowed for renewal and spiritual growth. The Rev. Jimmy Ezekiel took another call to St. Columba's Presbyterian Church in Zambia in 2001, and having returned from there he is now retired. The work in Phoenix continued under the supervision of the Rev. Brian van Niekerk as interim moderator and currently the Rev. Dr Chris Barnard oversees this work as interim moderator.

\section{Other Presbyterian Congregations}

The Presbyterian work among Indians was not limited to Durban. In the late 1970s and early 1980s many Indian folk moved from Durban to Johannesburg to seek better work opportunities. Elder George Soorie from the Merebank congregation moved with his family to Daxina in the south of Johannesburg. Consequently, with many more family members joining them they constituted a new congregation known as the Daxina Presbyterian Church under the care of the Egoli Presbytery. This work continued for many years under the supervision and ministry of Steven Pillay, a former elder in the Merebank congregation.

A further Indian work was started by Jerry Pillay in Lotus Park, Isipingo, in 1986, while he was completing his probation in the McDonald Memorial Presbyterian Church in Amanzimtoti. The Lotus Park Presbyterian Church started in the home of one family and within a period of 12 months grew into a church community of over 120 members. The church was situated in a very poor community and much of its ministry was centred on social and community development programmes. As a result of the latter, many people were attracted to the church, which continued to meet in a classroom in one of the schools in the area. In 1989 the Rev. Jerry Pillay took a call to a congregation in Bridgetown, Western Cape, and a few years later the then-Durban Presbytery decided to close down the work in Lotus Park. Rev. Pillay took a call to St. Andrew's in Benoni in 1998, where he ministered for just over 10 years. Dr Pillay was the first Indian minister to be elected moderator of the UPCSA General Assembly, serving from 2004 to 2006. He also served as moderator of the presbyteries of the Western Cape and Highveld. He served as general secretary of the UPCSA. In June 2010 he was elected as the first president of the World Communion of Reformed Churches (WCRC), in Grand Rapids, Michigan. The WCRC is a new body formed by the joining of the World Alliance of Reformed Churches and the Reformed Ecumenical Council, with a membership of over 80 million Reformed Christians across the world. 
Presently, there is a chuch in Mayfair that is a predominantly Indian congregation, although at one stage it was largely a white congregation. The Rev. Calvin Naidoo serves as minister in this congregation and he has been there for several years. Sunday services are held regularly, with certain ministries taking place during the course of the week. One of the most notable ministries in and through this local church is its care of refugees, especially from Pakistan. They have done so much to help integrate refugees into South African society by providing various forms of help with food, clothing, shelter, finding employment and help with ascertaining the necessary legal documents.

\section{Conclusion}

Although the Presbyterian work amongst Indians has not experienced substantial growth over the years, it is undoubtedly true to say that Presbyterian ministers, leaders and members from this community have made significant contributions to the development of Indian people in South Africa and to South Africa as a whole. Their work on the advancement, empowerment and development of the poor, women, youth and Indian people, in particular, speaks for itself, as we have shown. Presbyterians have always stressed the need to transform society as an integral part of their Christian spirituality and belief. It is thus not surprising that they played a pivotal role in the demise of apartheid and in the reconstruction of the new South Africa. Some of our Presbyterian Indian leaders are currently making significant contributions not only to South Africa but to Christian leadership and ecumenical movements across the world.

\section{Acknowledgements Competing interests}

The author declares that he has no financial or personal relationships that may have inappropriately influenced him in writing this article.

\section{References}

Adamson, R. (ed.), 2003, Presbyterian lay leaders' guidebooks, Uniting Presbyterian Church Publication, Brixton.

Brain, J.B., 1983, Christian Indians in Natal 1860-1911. An historical and statistical study, Oxford University Press, Cape Town.

Calpin, G.H., 1949, Indians in South Africa, Shuter \& Shooter, Pietermaritzburg.

Dalziel, J., 1982, The beginnings of Presbyterianism, PCSA Publication, Brixton.

De Gruchy, J.W., 2004, The Church struggle in South Africa. Twenty-fifth anniversary edition, SCM Press, London.

Duncan, G., 2003, Lovedale - Coercive Agency: Power and resistance in mission education, Cluster Publications, Pietermaritzburg, South Africa.

Duncan, G. \& Denis, P., 2011, The native school that caused all the trouble. A history of the federal theological seminary of Southern Africa, Cluster Publications, Pietermaritzburg, South Africa.

Hofmeyer, J.H. \& Oosthuizen, G.C., 1981, Religion in a South African Indian Community, Institute for Social and Economic Research, University of Durban-Westville, Durban.

Muller, C.F.J., 1984, 500 years: A history of South Africa, Academica, Pretoria.

Reim, E.P., 1975, The Presbyterian leadership, Vol. 24, PCSA, Johannesburg.

Rodger, A., 1998, A short history of the structures of general assembly, PCSA Publication, Brixton.

The Reformed Presbyterian Church in Southern Africa, 1996, Background paper to the basis of Union Debate, General Assembly Papers, PCSA, Johannesburg. 